\title{
The Most Effective Strategies to Curb Corruption and Improve Water Service Delivery in Zimbabwe
}

\author{
Patrick Mutuma*, Trevor Jambawo \\ Zimbabwe National Water Authority, Harare, Zimbabwe \\ tmutuma@zinwa.co.zw*, trevorjambawo@gmail.com
}

\begin{abstract}
The main objective of this study was to find the most effective strategies to curb and eradicate corruption and improve water service delivery. The study also aimed to present the type, causes, and effects of corruption. A mixed-methods questionnaire survey design was used to collect quantitative and qualitative data. 220 questionnaires were distributed to providers and users of water services in Zimbabwe. 149 respondents returned the completed questionnaires. Data were analysed using descriptive statistics and content analysis. The Analysis of Variance was used to test the significance of mean scores. The study revealed that corruption is highly prevalent in Zimbabwe. The main factors that cause corruption in the water sector are poor governance, economic hardship, and weak accountability. Corruption leads to economic stagnation and poor foreign investments. Organisations such as the Zimbabwe National Water Authority must improve systems and structures, enhance the auditing process, and educate staff on good ethical standards and effective governance to effectively fight against corruption and improve service delivery. They must also put in place strong governance and accountability frameworks and work closely with communities and policy makers to eradicate corruption. The availability of water should be the same across all the suburbs, and the country needs to adjust its water bill rates in line with regional rates. Service providers should make use of mobile technology to promote citizenry participation in sharing ideas and making decisions on water sustainability. This study reaffirms the need to fight corruption and improve water service delivery.
\end{abstract}

Keywords: Corruption, water service delivery, bribery, governance, economic growth

\section{Introduction}

Corruption is one of the most prevalent and least confronted challenges faced by public service institutions particularly in developing countries (Davies, 2004). Tizor (2009) observed that corruption in Zimbabwe had been normalisedin the public sector mainly due to economic problems. Civil servants go to work not only because they are paid wages but also because of the corrupt activities that enhance their paltry income. In water services, Sithole (2013) found that a client may pay a council worker in the form of a bribe to speed up a water reconnection or bribe to stop water disconnection for non-payment. As a result, the council is deprived of the funds that it could use to improve its service delivery.Bribery is one of the most common forms of corruption in the water sector. The water sector is characterised by several complex factors such as high demand for water services and monopoly, which increase the risk of corruption (Selamawit, 2015).Corruption has been getting worse over the years in Zimbabwe. The country was ranked 154 out of 175 countries by the Corruption Perception Index (CPI) in 2016 (Transparency International, 2016). The major problem of corruption is that it cripples the developmental efforts of African countries (Ijewereme, 2015). Seligson (2006) highlighted that corruption has serious effects on economic growth and democratic development. Corruption prevents potential investors from investing, distorts public expenditure, increases the cost of running businesses, the cost of governance and diverts resources from the poor to the rich among many other consequences (Ijewereme, 2015). Park \& Blenkinsopp (2011) posited that reducing corruption must, therefore, be of urgent priority to governments.

The main aim is to present empirical findings regarding the most effective strategies to curb and eradicate corruption and improve water service delivery. Also, the study aims to present the type, causes, and effects of corruption in the water sector. The study will also create greater awareness of corruption, improve transparency and accountability, and emphasise the need to tackle this pathological phenomenon. The most notable studies to highlight the need to research on corruption within the water sector include Hove \& Tirimbori (2011), Makanyeza et al. (2013), and Sithole (2013). This current study is of great importance because it is conducting a research specifically on corruption in water services in Harare and aims to make specific recommendations that deal with corruption. 
Background to Study: The World Bank (1997) defined corruption in detail as an illicit behaviour by officials in the private and public domain in which they improperly and unlawfully enrich themselves by abusing their job positions and misusing public power entrusted to them. This often leads to the embezzlement of funds, theft of corporate or public property, kickbacks in public procurement, nepotism as well as corrupt practices such as bribery, and extortion (Svensson, 2005). Van der Merwe (2006) argued that the abuse of public power is viewed as behavioural or structural. The behaviouraldimension refers to corruption committed by individuals or group of individuals through bribery, fraud and other forms of corrupt behaviour.This is referred to as personally corrupt behaviour because it benefits individuals, normally at the cost of an organisation (Banfield, 1975). The structural dimension refers to social, economic structures and processes in which corruption occurs (Van der Merwe, 2006). State enterprises and parastatals facilitate service delivery to both the public and corporate institutions and thus, influence economic activities and growth in various sectors (Moyo, 2012). According to Nsereko \& Kebonang (2005), aservice delivery of water, electricity, health, education, and housing is crucial to the growth and development of African economies. However, Makanyeza et al. (2013) discovered that corruption and lack of accountability and transparency were among the main causes of poor service delivery. Selamawit (2015) argues that lack of awareness, commitment, and understanding to apply anticorruption methods are some of the obstaclesfaced in fighting against corruption in the water sector. Attempts to improve water service delivery in Zimbabwe have been unsatisfactory mainly because of the water shortages that are prevalent across the country. Quite often, most suburbs in Harare do not have running water on weekends dueto either shortages or repairs (Nherera, 2016).

Water service availability is better in western suburbs than in eastern suburbs in Zimbabwe (Hove \& Tirimboi, 2011). Zimbabwe National Water Authority (ZINWA) argues that a substantial amount of unpaid water bills by individuals, mines, agricultural estates, government departments and local authorities are crippling the operations of the parastatal and preventing equitable access to essential water by all (Muvundusi, 2015). The Zimbabwean government's efforts to provide clean and efficient water supplies have been marred by allegations of corruption and lack of transparency. To date, debates on how best to improve efficiency and reliability of water supplies, while curbing corruption, are still raging on (Sithole, 2013). Selamawit (2015) suggested the involvement of the community, the private sector, and civil societyto collectively fight corruption and minimise the monopolistic nature of the service.

Research Questions: Defined questions make it possible to find evidence-based solutions to the problem of corruption in the water services (Davies, 2011). Question 1 is the main research question. Questions 2 to 5 are the sub-questions that this study is attempting to answer.

- What are the most effective strategies to curb and eradicate corruption and improve water service delivery?

- Which types of corruption are the most common in the water sector?

- What factors or circumstances influence corruption in the water sector?

- What are the effects or consequences of corruption?

\section{Literature Review}

Theories of Corruption: Corruption is characterised by a range of factors such as economic and social and is the result of dynamic relationships between individuals, groups, institutions, the private sector, the public sector and the state (Department for International Development, 2015). It is for this reason that Breit et al. (2015) believed that undertaking more theoretical reflections on corruption can help to understand the meaning of it as well as findbetter ways to eradicate it. Marquette \& Peiffer (2015) also suggested that anticorruption interventions need to better understand, from a theoretical perspective, why corruption can be usedby people as a problem-solving approach, particularly in weak institutional environments. According to Persson et al. (2013), the principal-agent theory explains the conflict that arises between principals who look after the public interest and agents who engage in corrupt activities. Booth (2012) observed that with this theory, agents undermine the principal's interest in pursuit of their interests through corruption. A principal is unable to monitor an agent effectively, normally due to lack of information. Chakrabarti (2000) tested the agent-based theory of corruption and found that corruption at the individual level leads to corruption at a societal level. 
The predominant theoretical approach to corruption has always been based on a principal-agent model discussed above. More recently, corruption has been viewed from a collective action perspective, whereby all stakeholders including bureaucrats, rulers, and citizens are participants of corruption (Department for International Development, 2015). These stakeholders weigh the rewards and costs of corruption such that, for example, a citizen may be corrupt because the costs of not being corrupt or acting in a more principled manner far outweigh the benefits (Persson et al., 2013). A collective action theory purports that the same corrupt behaviour and decisions made by individuals occur but within a wider society. When corruption occurs collectively, it becomes systemically pervasive and difficult to monitor and control as people may lack the will to act (Marquette \& Peiffer, 2015). The public choice theory is when an official makes a choice to act corruptly, and the organisational culture theory is when a group culture and aspects of the workplace encourage an official to act corruptly (De Graaf, 2007).

Forms of Corruption: Corruption exists in many forms at various levels of service delivery. Corruption normally occurs in the form of embezzlement, procurement scam, extortion, bribery, fraud, kickback, gifts and tips, nepotism and tribalism in recruitment, appointment, or promotion, misappropriation of public funds, institutionalized, and leaking tender information to friends and relatives (Nsereko \& Kebonang, 2005; Ijewereme, 2015; Selamawit, 2015). In Zimbabwe, Makumbe (2011)found that bribery is the most common form of corruption whereas extortion is the least form of corruption.Bribery is payment in the form of money or kind given to or taken by state officials engaged in corrupt activities (Selamawit, 2015). Davies (2004) found that clients were paying bribes directly to employees from as little as US $\$ 2$ for a repair request to US $\$ 22$ for a new connection. Seligson (2006) argues that some bribe payers may not be victims as they claimsince they willingly participant in such transactions to advance their aims.

Causes of Corruption: Corruption is a complex and multi-faceted phenomenon characterised by a range of economic, political, administrative, social and cultural factors as shown in Table 1. Centralisation of power, poor governance, weak accountability and incomplete economic liberalisation enable and foment corruption (Mills, 2012; Department for International Development, 2015). Treisman (2000) established some hypotheses which state that corruption is typically lower in democratic and, or economically developed countries, and countries with a freer press and more vigorous civic associations. Corruption is higher in countries with greater political instability. Furthermore, corruption is typically lower in countries with common law systems. According to Saki \& Chiware (2007), Zimbabwe's legal system is made up of common law as well as customary and legislation law.In that light, we will establish whether the hypotheses by Treisman (2000) hold in the case of Zimbabwe.Goel \& Nelson (2008) also found that countries using acommon-law system seem to have lower corruption. This is because a legal framework provides a systematic set of auditing as well as severe repercussions for people involved. They also discovered that economic prosperity and democratic tendencies in a country leads to lower corruption.

\section{Table 1: Factors which optimise the occurrence of corruption}

\begin{tabular}{ll}
\hline Poor governance & Weak accountability \\
Individual beliefs & Low salaries \\
Addiction of alcohol/drugs/gambling & Democratic countries \\
Employee dissatisfaction & Legal system \\
Work pressures & Political instability \\
\hline
\end{tabular}

Source: Treisman (2000); Mills (2012) and Department for International Development (2015)

Causes of Poor Service Delivery: Makanyeza et al. (2013) discovered that corruption and lack of accountability and transparency were among the main causes of poor service delivery. The other major causes were councillor interference, political manipulation, poor human resource policy, lack of employee capacity, inadequate citizen participation, substandard planning, and poor monitoring and evaluation. Mtisis (2008) found that the underlying causes hindering the provision of clean water to Zimbabwe's urban areas include corruption, economic stagnation, political interference, population growth, dilapidation in water infrastructure, and not following water quality standards and laws. Of importance were the findings by Hove \& Tirimbori (2011) who found that poor water service delivery was mainly due to low production and high non-revenue water, which stood at almost 40 percent. In addition, lack of a satisfactory regulatory board which can deal with residents' complaints on water issues affecting them is a major factor. Lastly, water bills 
in Zimbabwe were higher when benchmarked against those of developed and developing countries, which made some residents struggle to pay their monthly bills.

Effects of Corruption: The common effects of corruption in the water sector are worsening poverty, reduced productivity, poor quality of service and lack of accountability and transparency (Selamawit, 2015). Corruption undermines the provision of clean water and effective water service delivery (Mtisis, 2008) and stalls progress towards an inclusive society, both economically and socially (Nsereko \& Kebonang, 2005). According to Hove \& Tirimbori (2011), poor water service delivery in Harare saw residents getting supplied with only a third of the total demand, consequently forcing residents to use unhygienic strategies such as drinking water from unsafe boreholes. In the past, unrelenting water problems have brought the cholera epidemics that led to many people dying from using contaminated water. Corruption is a stumbling block to Zimbabwe's development as well as Southern African Development Community (SADC) region's development. Corruption in one country exacerbates all the other problems that beset the region. Corruption has a negative impact on the well-being and welfare of the general populace (Nsereko \& Kebonang, 2005), as its effects include the abuse of national resources, underdevelopment, high unemployment and poor standard of service delivery (Ijewereme, 2015).

Figure 1: Corruption Perception Index ranking against ZSE Mining Index

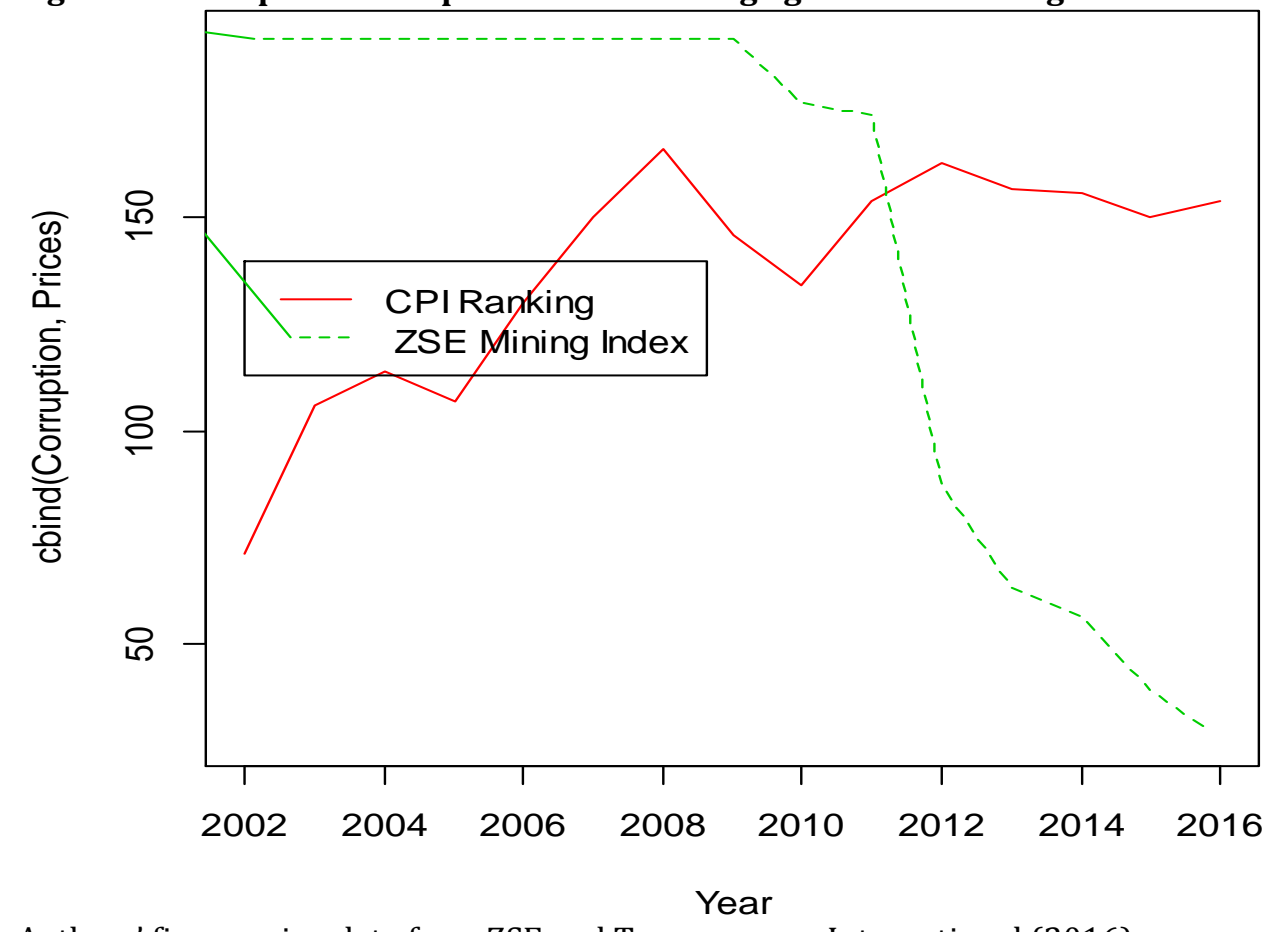

Authors' figure using data from ZSE and Transparency International (2016)

Figure 1 shows a steep downward trend for the Zimbabwe Stock Exchange (ZSE) Mining Index and a relatively upward trend for Zimbabwe's corruption rating. As corruption has been getting worse, the index has also been increasingly performing badly. Zimbabwe was ranked 71 in 2002, 107 in 2005, 146 in 2009 and 154 in 2016 for corruption. On the other hand, the yearly averaged price of the ZSE Mining Index was US\$192 in 2009 , US\$87 in 2012 , US\$56 in 2014 and US\$28 in 2016 . We could not compute the prices of the index from 2002 to 2008 because they were quoted in Zimbabwean dollars and part of that period had hyperinflation. We argue that corruption is one of the main factors influencing the underperformance of the index because investors become bearish and risk averse in sectors or countries with rampant corruption. Our argument is supported by the findings ofTransformation Index (2016) who found that the mining sector in Zimbabwe is particularly affected by high-level corruption and patronage. Selamawit (2015) postulated that corruption in the public service prevents both domestic and foreign investors from investing in an economy. This is because corruption erodes trust and confidence of a nation (Seligson, 2006). Davies (2004) also found 
that corruption stifles development opportunities available to developing countries as investments become less productive and the cost of capital increases.

Strategies to Curb Corruption \& Improve Service Delivery: The fight againstcorruption requires wellcoordinated efforts and teamwork from all stakeholders, including the community and civil society groups (Selamawit, 2015). According to Mills (2012, p.1), "social psychology, organisational theory, social theory, business ethics, criminology and behavioural economics, among others, all have something to offer the corruption prevention endeavour". Employing information technology to decrease discretion, engaging nongovernmental organisations (NGOs) and communities to monitor projects (Davies, 2004), ensuring customers participate in the decision-making process and improving systems and structures are some of the strategies that can be used to reduce incidences of corruption (Selamawit, 2015). Ncube \& Maunganidze (2014) concurred by suggesting that maintaining good ethical standards and good governance should make leaders in parastatals positively turn the fortunes of the country. Countries need leaders of substance who possess good leadership qualities and unbridled commitment to public good. If leaders are not trustworthy, this will cascade to the bottom of the organisation and lead to a decline in the business as well as the country's economy. The management of Harare City Council (HCC) rewarded itself hefty salaries and allowances despite poor water service delivery, a poor economic performance (Ncube \& Maunganidze, 2014) and paltry employee income (Zhou, 2012).

Auditing can help to curb corruption because auditors can take appropriate action if they find facts which give them areason to believe that a corrupt activity amounting to an irregularity has been committed. The possible effects of the corrupt activity will also be documentedin the audit report (Labuschagne \& Els, 2006). Unfortunately, Bussell (2010) found that policy initiatives intended to reduce corruption are least likely to be implemented in countries that have high levels of corruption. Dealing with corruption is one way of improving water service delivery. The other primary strategies to improve service delivery include timely response to client complaints, partnership with the community, citizen participation in the affairs of the local authority, ensuring that clients pay their bills on time, strategic public service planning, solid human resource policy, outsourcing services, improving accountability, segregation of duties between councillors and management of the local authorities (Makanyeza et al., 2013).

\section{Methodology}

Research Method: This study used a mixed-methods questionnaire survey design to collect both qualitative and quantitative data. Two questionnaires with semi-structured (closed and open-ended) questionswere designed for service providers and service users within the water service sector in Zimbabwe. The qualitative approach aims to give a detailed description whereas the quantitative approach aims to explain what is observed with regards to corruption (Leedy \& Ormrod, 2013).

Sampling Method\& Sample Size: A total of 110 questionnaires were distributed to clients, and 110 questionnaires to ZINWA staff based on anon-response rate of 10 percent. Clients were carefully chosen using the probability method known as stratified random sampling where each person of the target populace had anequal chance of being selected (Kelly et al., 2003). The sampling method used to select service providers was the non-random, purposive sampling method. Purposive sampling was used to purposely provide diverse perspectives and data on the issue of corruption from experienced ZINWA staff (Cresswell, 2007). The inclusion criteria for service users was that they should be aged over 20 years, homeowners or tenants responsible for paying water bills, and English literate. The inclusion criteria for staff was that they should be working for ZINWA, aged over 20 years, English literate, and with no formal disciplinary against corruption. The sample size of clients $(n=77)$ gave a response rate of 70 percent. The sample size of service providers $(n=72)$ gave a response rate of 65.4 percent. One of the disadvantages of using a questionnaire is that it can have low response rate (Synodinos, 2003). In this study, the relatively good response rates might have been a result of the simplicity of the questionnaires. Also, the potential problem of low response rates was initially addressed by clearly explaining the nature and purpose of the research to participants. Participants were also told of the estimated time to complete the questionnaire to encourage participation. 
Data Collection: Aquestionnaire survey was used to collect rich data and assess the thoughtsand experiences of participants (Bryman \& Bell, 2007). This data collection instrument had both close-ended Likert-type questions and open-ended questions targeted at staff and customers. This instrument collected both numerical and categorical data from respondents. The following literature played a crucial role in formulating the research questions and survey questions (Davies, 2004; Nsereko \& Kebonang, 2005; Seligson, 2006; Hove \& Tirimboi, 2011; Mills, 2012; Makanyeza, et al., 2013; Ncube \& Maunganidze, 2014; Department for International Development, 2015; Ijewereme, 2015; Selamawit, 2015).

Data Analysis: The Likert-type questions are best analysed using descriptive statistics. Descriptive statistics were created by calculating a composite score (mean) for central tendency from the five Likert-type items (1 $=$ strongly agree to $5=$ strongly disagree) (Likert, 1932). The Analysis of Variance (ANOVA) test was used to test whether mean scores were significantly different from 3, the score for neutrality (Boone Jr \& Boone, 2012). A mean score below 3 and significantly different from 3 meant that the overall view of respondents was not neutral and was either closer to 1 for strong agreement or closer to 2 for just in agreement. A mean score above 3 and significantly different from 3 meant that the overall view of respondents was not neutral and was either closer to 4 for just in disagreement or 5 for strongly in disagreement. The qualitative data wereanalysed using content analysis. Content analysis is an approach which objectively and systematically identifies and summarises written or spoken communication into fewer content categories (Steve, 2001).

Ethical Considerations: The study was approved by the University of South Africa (UNISA) Research Ethics Committee and by the management of Zimbabwe National Water Authority. Participants were provided with a questionnaire and a clear verbal explanation of the purpose of the study. They were not asked for their names to ensure confidentiality. Participants were assuredofconfidentiality and integrity and that they had the right to decline to participate or withdraw from the study at any time. Consent of staff and service users was implied from thereturn of the completed questionnaire. Other ethical principles adhered to in this study include honestly reporting data, methods, and results and avoiding careless errors. As emphasised by Resnick (2015), fairness, honesty, trust, respect, accountability, and making rational decisions were observed throughout the study.

\section{Results \& Discussion}

Profile of Respondents: The profile of the service users and service providers with regards to gender, age and qualifications are summarised in Table 2.Most clients (55 percent) were males, and 45 percent were females. Much of service providers (64 percent) who participated in the survey were male, and 36 percent were female.Most of the clients (31 percent) who participated in the survey were in the group aged 20-29 years, and the same proportion was in the group aged 30-39 years. About 21 percent of surveyed clients were aged 40-49 years, and 17 percent were above 50 years of age. The results indicate that majority of the service users are in their early adulthood. About half of the service providers surveyed were aged 30-39 years, 23 percent were aged 40-49 years, 14 percent were aged 20-29 years, and 11 percent were above 50 years of age. The results indicate that majority of the staff at ZINWA are in their young and middle adulthood.

Table 2: Main respondent characteristics (valid responses and \%)

\begin{tabular}{lllll}
\hline & $\begin{array}{c}\text { Clients } \\
\text { Frequency }(\boldsymbol{n})\end{array}$ & $\begin{array}{c}\text { Service Providers } \\
\text { Percentage } \\
\text { F\%) }\end{array}$ & Frequency (n) & $\begin{array}{l}\text { Percentage } \\
(\%)\end{array}$ \\
\hline Gender & & & & \\
Male & 42 & 55 & 46 & 64 \\
Female & 35 & 45 & 26 & 36 \\
Age & & & 10 & 14 \\
$20-29$ & 24 & 31 & 37 & 51 \\
$30-39$ & 24 & 31 & 17 & 23 \\
$40-49$ & 16 & 21 & 8 & 11 \\
Above 50 & 13 & 17 & &
\end{tabular}




\begin{tabular}{lllll} 
High school & 13 & 17 & 4 & 6 \\
Diploma & 27 & 35 & 22 & 31 \\
Bachelor's degree & 32 & 42 & 29 & 40 \\
Master's degree & 5 & 6 & 17 & 24 \\
\hline
\end{tabular}

Most of the surveyed clients (42 percent) had a first degree, 35 percent had a diploma, 17 percent had completed high school, and 6 percent had a Master's degree. Many of the service providers ( 40 percent) had a first degree, 31 percent had a diploma, 24 percent had a Master's degree, and 6 percent had completed high school. The results indicate that employees of ZINWA aremore educated as evidenced by more postgraduate studies, which is important in providing good quality service to the public.

Availability of Water: High-density suburbs such as Glen View, Budiriro, and Ruwa have poor availability of water. The results in Figure 2 show that majority of clients (27 percent) did not have water for 8-14 days, 25 percent did not have water for 1-7 days, 17 percent did not have water for 22-30 days, and 16 percent did not have water for 15-21 days per month. Overall, the average number of days that households did not receive water was 11 days per month. A minority of clients (15 percent) reported that they were not experiencing any water cuts.

Figure 2: Number of days clients had no water per month

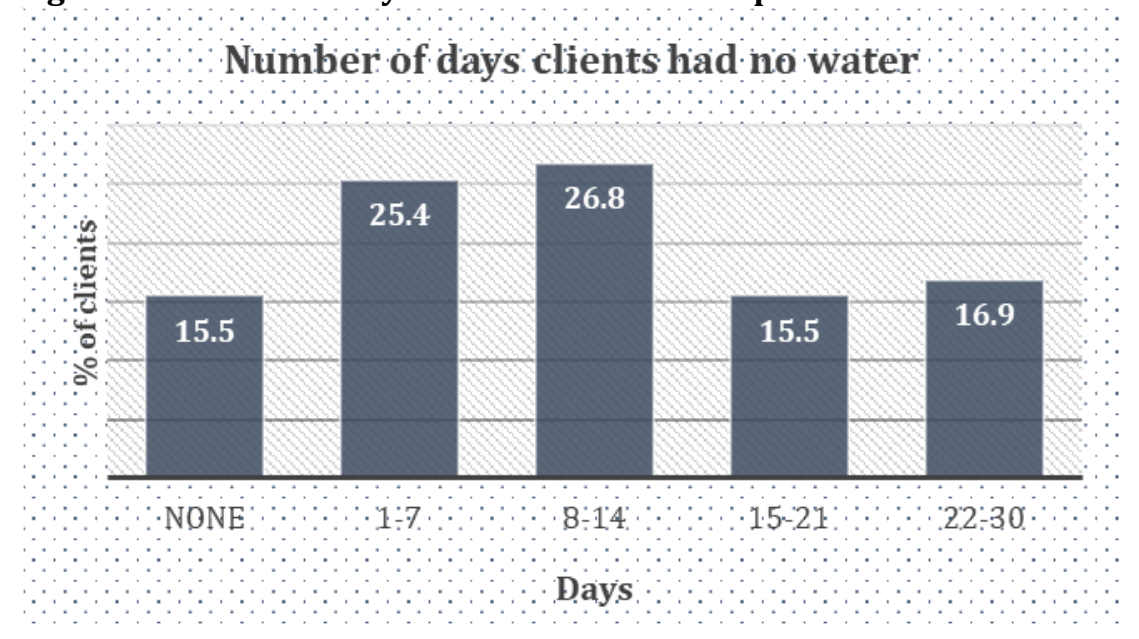

Causes and Effects of Corruption: Clients and service providers were asked to indicate the extent to which they agreed with the statement that each identified risk factor contributes to a high level of corruption. As shown in Table 3, the ANOVA test revealed that clients were strongly in agreement with the suggestion that poor governance, economic hardship, weak accountability and low salaries contribute to high levels of corruption in the water sector since the mean scores were less than 2 and significantly below 3 (p value $=0.000$ ). The ANOVA test also revealed that service providers strongly agree that poor governance, weak accountability, economic hardship and employee discontent promote high corruption in the water sector since the mean scores were less than 2 and significantly below 3 ( $\mathrm{p}$ value $=0.000$ ).

Table 3: Views of respondents on factors that contribute to corruption

\begin{tabular}{lllll}
\hline & $\begin{array}{c}\text { Clients } \\
\text { Mean of Likert } \\
\text { scores }\end{array}$ & $\begin{array}{l}\text { p-value on } \\
\text { statistical } \\
\text { difference from 3 }\end{array}$ & $\begin{array}{l}\text { Service Providers } \\
\text { Mean of Likert }\end{array}$ & $\begin{array}{l}\text { p-value on } \\
\text { statistical } \\
\text { difference from 3 }\end{array}$ \\
\hline Poor Governance & 1.60 & 0.000 & 1.76 & 0.000 \\
Economic hardship & 1.62 & 0.000 & 1.65 & 0.000 \\
Weak Accountability & 1.87 & 0.000 & 1.66 & 0.000 \\
Low Salaries & 1.90 & 0.000 & 2.14 & 0.000 \\
Political Instability & 2.31 & 0.000 & 2.24 & 0.000
\end{tabular}




\begin{tabular}{lllll} 
Employee Dissatisfaction & 2.32 & 0.000 & 1.87 & 0.000 \\
Work Pressure & 3.62 & 0.000 & 3.32 & 0.011 \\
\hline
\end{tabular}

Clients also concurred that political instability and employee dissatisfaction contribute to high levels of corruption since mean scores from the ANOVA test were significantly less than 3. Service providers were also in agreement that low salaries and political instability contribute to high levels of corruption since mean scores from the ANOVA test were significantly less than 3. Clients and service providers disagreed with the suggestion that work pressure contributes to high levels of corruption since mean values from the ANOVA test where found to be significantly above 3.The results of this study are in line with the findings by the Department for International Development, (2015), Treisman (2000) and Mills (2012), who also found that poor governance, low salaries, economic hardship, weak accountability, political instability and employee dissatisfaction are factors that enable the occurrence of corruption.Porkess (2011) explained that work pressure does not necessarily lead to a corrupt culture, a reasoning which is shared by participants in this study. However, the author further asserts that work pressure can be a critical first step to corrupt behaviour if other conditions permit so. Once corrupt behaviour takes hold, it is difficult to control it and will have disruptive consequences to service delivery and the business.

Service providers were asked to indicate the extent to which they agreed with the statement that each identified effect of corruption had the suggested effect. Mean scores less than 2 and p-values much less 0.05 from the ANOVA test revealed that service providers strongly agreed with the view that corruption has a negative effect on economic growth, potential investors, costs of running businesses, public expenditure, quality of service and worsens poverty (see Table 4). Although service providers agreed that corruption hinders democratic development, it is the least they think can be affected by corruption.Just like our findings, Seligson (2006) and Selamawit (2015) also found that corruption stalls economic growth. Seligson (2006) asserts that if corruption is the cause of poor economic performance, then anti-corruption programs become relevant to use to fight corruption unlike if it was the other way around. Nsereko \& Kebonang (2005) and Ijewereme (2015) also support our finding that corruption interrupts a conducive environment for potential investors to invest in the economy of a country. It is imperative that corruption across all sectors is managed effectively considering that most of the firms in Zimbabwe rely on external investors for financing (Jambawo, 2014) and those investments bolster economic growth of the country in return (Zivengwa et al., 2011).

\section{Table 4: Views of service providers on some of the most damaging effects of corruption}

\begin{tabular}{lll}
\hline & $\begin{array}{l}\text { Mean of Likert } \\
\text { scores }\end{array}$ & $\begin{array}{l}\text { p-value on statistical } \\
\text { difference from 3 }\end{array}$ \\
\hline Economic growth & 1.55 & 0.000 \\
Scares potential investors from investing & 1.57 & 0.000 \\
Increases cost of running businesses & 1.73 & 0.000 \\
Distorts public expenditure & 1.87 & 0.000 \\
Poor quality of service & 1.87 & 0.000 \\
Worsens poverty & 1.90 & 0.000 \\
Democratic development & 2.47 & 0.000 \\
\hline
\end{tabular}

Forms of Corruption: Clients and service providers agreed with the statement that each identified type of corruption is common in the water sector. As shown in Table 5, the ANOVA test revealed that clients were strongly in agreement with the suggestion that bribery is a common type of corruption in the water sector since the mean score was found to be less than 2 and significantly below 3 ( $p$ value $=0.000$ ). Service providers were also in agreement with the suggestion that bribery is a common type of corruption in the water sector since a mean score of 2.14 was found to be significantly below 3. The ANOVA test also revealed that clients and service providers agreed with the suggestion that fraud, kick-backs, gifts and tips, embezzlement and institutionalised corruption are common types of corruption in the water sector since the mean scores were significantly below 3 ( $\mathrm{p}$ value $=0.000$ ). 
Table 5: Views of respondents on common types of corruption in the water sector

\begin{tabular}{lllll}
\hline & $\begin{array}{c}\text { Clients } \\
\text { Mean of Likert } \\
\text { scores }\end{array}$ & $\begin{array}{l}\text { p-value on } \\
\text { statistical } \\
\text { difference from 3 }\end{array}$ & $\begin{array}{l}\text { Service Providers } \\
\text { Mean of } \\
\text { Likert scores }\end{array}$ & $\begin{array}{l}\text { p-value on } \\
\text { statistical } \\
\text { difference from 3 }\end{array}$ \\
\hline Bribery & 1.68 & 0.000 & 2.14 & 0.000 \\
Fraud & 2.03 & 0.000 & 2.26 & 0.000 \\
Institutionalized & 2.19 & 0.000 & 2.00 & 0.000 \\
Kick-back & 2.21 & 0.000 & 2.07 & 0.000 \\
Embezzlement & 2.27 & 0.000 & 2.48 & 0.000 \\
Extortion & 2.38 & 0.000 & 2.74 & 0.077 \\
Gifts and Tips & 2.56 & 0.001 & 2.11 & 0.000 \\
\hline
\end{tabular}

A p-value well below 0.05 from the ANOVA test showed that clients viewed extortion as a common type of corruption in the water sector, but a p-value above 0.05 showed that service providers did not view extortion as a common type of corruption in the water sector. Similarly, Makumbe (2011) found that bribery is the most common form of corruption and extortion is the least form of corruption. Extortion is probably unpopular because it happens when service providers extract payments from unwilling clients (Gray\& Kaufmann, 1998). Our findings on fraud differ with the findings by Selamawit (2015) in that a small proportion (3 percent) of their participants believe fraud is a recognised form of corruption in the water supply and sanitation sector in Ethiopia. In our sample, fraud was the second most common type of corruption in the water sector.Clients were asked to indicate the extent to which they agreed that bribery was most likely to occur in each identified situation in water service delivery. Mean scores less than 2 and pvalues much less 0.05 from the ANOVA test revealed that clients were strongly in agreement with the suggestion that bribery is most likely to occur when avoiding a water cut after failing to pay water bills, when speeding up a new connection and when speeding up a reconnection (see Table 6). A p-value less 0.05 from the ANOVA test revealed that clients agreed with the view that bribery is most likely to occur when there are service repairs. Sithole (2013) explained that employees in the public sector create delays to manufacture a crisis, which often leads to a bribe being paid by clients to speed up various processes or to get services.

Table 6: Views of clients on when bribery is most likely to occur

\begin{tabular}{lll}
\hline & $\begin{array}{l}\text { Mean of Likert } \\
\text { scores }\end{array}$ & $\begin{array}{l}\text { p-value on statistical } \\
\text { difference from 3 }\end{array}$ \\
\hline When avoiding water cut after failing to pay water bills & 1.49 & 0.000 \\
When speeding up a new connection & 1.92 & 0.000 \\
When speeding up reconnections & 1.87 & 0.000 \\
When there are service repairs & 2.73 & 0.022 \\
\hline
\end{tabular}

Strategies to Curb Corruption: Service providers were asked to indicate the extent to which they agreed with the statement that each identified strategy was the most effective in curbing corruption and improving service delivery. Mean scores less than 2 and p-values much less 0.05 from the ANOVA test revealed that service providers strongly agreed with the suggestion that maintaining good ethical standards and good governance, auditing and improving systems and structures are the most effective strategies to curb corruption and improve service delivery. P-values less 0.05 from the ANOVA test showed that service providers agreed with the suggestion that implementing Information Technology, ensuring customers participate in decision making and, engaging NGOs and communities to monitor projects are effective strategies that can reduce corruption and improve service delivery (see Table 7).

Table 7: Views of service providers on the most effective strategies

\begin{tabular}{lll}
\hline & $\begin{array}{l}\text { Mean of Likert } \\
\text { scores }\end{array}$ & $\begin{array}{l}\text { p-value on statistical } \\
\text { difference from 3 }\end{array}$ \\
\hline Maintaining good governance and ethical standards & 1.30 & 0.000 \\
Auditing & 1.70 & 0.000 \\
Improving systems and structures & 1.70 & 0.000
\end{tabular}


Implementing Information Technology

Ensuring customers participate in decision making

Engaging NGOs and communities to monitor projects
2.04

2.17

2.68
0.000

0.000

0.000

The obstacles that staff face in fighting corruption effectively include lack of commitment, lack of combined effort by all stakeholders, nepotism, late payment of salaries, low salaries, kickbacks, fear of victimisation and lack of modern management systems as shown in Table 8. A summative content analysis revealed that lack of commitment was the major obstacle faced bystaff in eradicating corruption. Fear of victimisation and receiving kickbacks if you report, particularly senior persons, were also common challenges.

Table 8: Factors which makes it difficult to fight corruption

\begin{tabular}{lll}
\hline Lack of commitment & Nepotism & Kickbacks \\
Lack of modern management systems & Poor coverage of water services & Compromised systems \\
Late payment of salaries & Low salaries & Fear of victimisation \\
Low morale at work & Political interference & Concealment of the act \\
\hline
\end{tabular}

As shown in Figure 3, 79 percent of the service providers feel that the legal system in Zimbabwe must be helping to curb corruption. This finding is in line with the findings by Moyo (2012) who found that Zimbabwe has a concrete legal and constitutional framework to fight corruption but lacks the political will to address the problem. People do not hesitate to commit a crime if they know they can get away with it (Treisman, 2000). The Prevention of Corruption Act 1983 criminalises all forms of active and passive corruption in both the public and private sectors. This legislation punishes guilty agents through hefty fines, or imprisonment (Gan Integrity, 2017). Other legislations that deal with corruption offences include the Anti-Corruption Commission Act 2004 and the Criminal Procedure and Evidence Amendment Act 2004 (Chene, 2015). Given that Zimbabwe's legal system is made up of common law, the country must be having lower corruption like other countries using the same system (Goel \& Nelson, 2008).

\section{Figure 3: Views of Service Providers on Zimbabwe's Legal System}

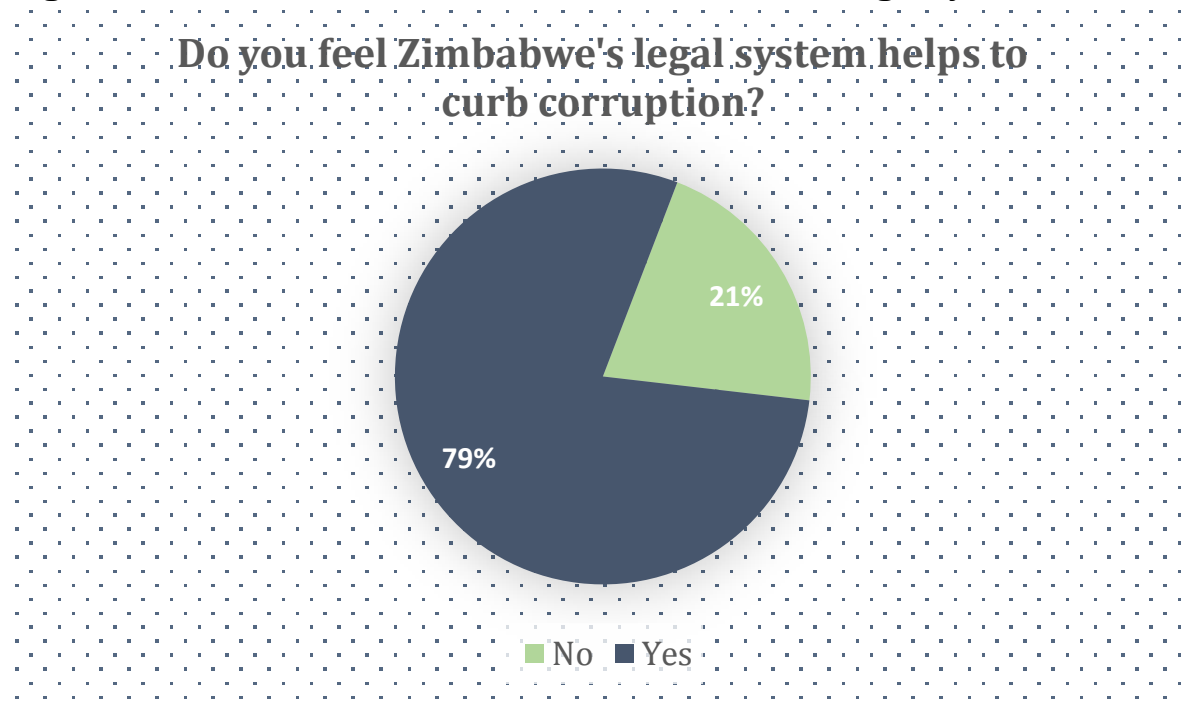

Service Delivery: Clients were asked to indicate the extent to which they agreed with the statement that each identified factor was a cause for poor water service delivery. Clients were strongly in agreement with the view that lack of accountability, dilapidation in water infrastructure and failure to follow quality standards and laws are factors that cause poor service delivery in addition to corruption since Likert scores were less than 2 and p-values from the ANOVA test were well below 0.05 (see Table 9). 
Table 9: Views of clients on factors that cause poor water service delivery

\begin{tabular}{lll}
\hline & $\begin{array}{l}\text { Mean of Likert } \\
\text { scores }\end{array}$ & $\begin{array}{l}\text { p-value on statistical } \\
\text { difference from 3 }\end{array}$ \\
\hline Lack of accountability and transparency & 1.84 & 0.000 \\
Dilapidation in water infrastructure & 1.95 & 0.000 \\
Not following quality standards and laws & 1.99 & 0.000 \\
Low production & 2.00 & 0.000 \\
Lack of planning & 2.08 & 0.000 \\
Lack of regulation & 2.23 & 0.000 \\
Economic challenges & 2.30 & 0.000 \\
Lack of payments due to high water bills & 2.31 & 0.000 \\
Political Interference & 2.39 & 0.000 \\
Inadequate citizen participation & 2.51 & 0.000 \\
Population growth & 2.77 & 0.130 \\
Lack of employee capacity & 2.78 & 0.063 \\
\hline
\end{tabular}

As shown in Table 9, clients agreed with the view that low production, lack of regulation, lack of planning, economic challenges, non-payment of water bills, political interference and inadequate citizenry participation are factors that cause poor service delivery in the water sector in addition to corruption since mean scores were found to be significantly below 3 . On the other hand, clients were relatively neutral on the suggestion that population growth and lack of employee capacity are factors that cause poor water service delivery in addition to corruption since the mean scores were found not to be significantly below 3 .

\section{Conclusion \& Recommendations}

Limitations: The main limitation of this study is that it was only conducted on services users and staff in Harare. This may affect the generalizability of the results to other regions of Zimbabwe. Although the response rate for service users and service providers was relatively good (68 percent), it might have been better if the length of time required to fill in the questionnaires was not that long.

Conclusion: The results on the research questions are revealed in this paragraph. Bribery is the most common type of corruption in the water sector, and it normally occurs when avoiding water cut after failing to pay a water bill, and when speeding up a reconnection or a new connection. Fraud, kick-back, institutionalised, embezzlement and gifts and tips are also popular in the water sector. The results revealed that poor governance, economic hardship, weak accountability, low salaries, employee dissatisfaction and political instability are risk factors of corruption in the water sector. Both clients and service providers do not view work pressure as a contributory factor of corruption. The results revealed that corruption has a negative effect on economic growth, potential investments, costs of running businesses, public expenditure, quality of service and the public's well-being and prosperity. However, maintaining good ethical standards and good governance and improving systems and structures are effective strategies that can curb corruption and improve service delivery. Furthermore, implementing information technology and ensuring inclusivity in making decisions on water projects are strategies that can help manage corruption and improve service delivery. Service providers cited lack of commitment, lack of teamwork, nepotism, late payment of salaries, low salaries, kickbacks, fear of victimisation and lack of modern management systems as obstacles they face in fighting corruption effectively.

The principal-agent theory and public choice theory are linked to the study findings because employees (agents) choose to undermine their organisation's (principal) interest in pursuit of their interests by behaving corruptly (Booth, 2012). This behaviour does not only affect the principal, but it also discourages investorsfrom investing and slows theeconomic growth of the country. Apart from corruption, the results revealed that lack of accountability, dilapidation in water infrastructure and failure to follow quality standards and laws are also major factors causing poor water service delivery. Also, low production, lack of regulation, lack of planning, economic challenges, non-payment of water bills, political interference and inadequate citizenry participation are factors that cause poor service delivery in the water sector. Attempts to 
improve water service delivery in Zimbabwe have been exacerbated by the water shortages that are prevalent in the country. This research found that water availability is poorer in high-density suburbs compared to western and northern suburbs. Overall, the average number of days that households do not have water is 11 days per month. Most suburbs in Harare do not have running water mostly on weekends due to either shortages or service repairs.

Implications for Practice \& Policy: Water service providers and local authorities across the country must put in place strong governance and accountability frameworks to minimiseand eradicate corruption practices by their employees.Service providers also need to address obstacles, such as poor teamwork, lack of commitment, nepotism, late payment of salaries, low salaries and fear of victimisation, that honourableemployees face in trying to fight corruption effectively. An incentive that rewards employees who show commitment to fight corruption might be worth introducing.Given that bribery is likely to happen when avoiding water cut off due to non-payment or when speeding up a new connection or reconnection, measures should be put in place to prevent this form of corruption from occurring. Measures may include anonymous hotlines where clients can phone to report such matters. These lines may be run by an audit firm to ensure accountability of reported cases and identity protection of whistleblowers.Employees should receive punitive punishmentfor violating company ethics and public laws on corruption. Policy makers must address the impediments that frustrate the Zimbabwean justice system indealing with corrupt officials. This should help reduce corruption across all sectors in the country and consequently attract the much-needed local and foreign investments.

Recommendations: The availability of water should be the same across all the suburbs of Harare. Areas that do not have the provision of council water must urgently be prioritised to have a water service in place. Also, Zimbabwe needs to adjust its water bill rates in line with regional rates. High water bills are one of the reasons why service users struggle to pay water bills.ZINWA and HCC must improve their systems and structures, enhance their auditing process, and educate their staff on good ethical standards and good governance to effectively fight against corruption and improve water service delivery.ZINWA must closely work with Transparency International as a way of strengthening stakeholder collaboration in the fight against corruption. Councils are recommended to review their revenue collection systems and introduce efficient systems that boost revenue collection. This will enable the councils to effectively deal with cash flow problems that contribute to low salaries and late payment of salaries which have been highlighted as some of the determinants of corruption.Service providers must make use of mobile technology to promote citizenry participation in sharing ideas and making decisions on water sustainability.There is an urgent need to deal with corruption, improve transparency and accountability, improve water infrastructure, follow quality standards and laws and increase the production of water to improve service delivery.

Acknowledgements: The authors would like to thank Professor AJ Smit for his guidance, T Muzondo for his support, anonymous reviewers for helpful comments, and UNISA and ZINWA for making this study possible.

\section{References}

Banfield, E.C. (1975). Corruption as a feature of governmentalorganization. Journal of Law and Economics, 18, 587-605.

Boone Jr, H.N. \& Boone, D.A. (2012). Analyzing Likert Data.The Journal of Extension, 50(2), 1-5.

Booth, D. (2012). Development as a Collective Action Problem: Addressing the Real Challenges of African Governance. London: Overseas Development Institute.

Breit, E., Lennerfors, T.T. \& Olaison, L. (2015). Critiquing corruption: A turn to theory.Ephemera: theory \& politics in organization, 15(2), 319-336.

Bryman, A. \& Bell, E. (2007). Business research methods (2nd Ed), New York: Oxford University Press.

Bussell, J.L. (2010). Why Get Technical? Corruption and the Politics of Public Service Reform in the Indian States. Comparative Political Studies, 43(10), 1230-1257.

Chakrabarti, R. (2000). Corruption: A General Equilibrium Approach. Paper presented in Conference of Computing in Economics and Finance, Barcelona.

Chene, M. (2015). Zimbabwe: Overview of corruption and anti-corruption. Anti-corruption resource centre. 
Creswell, J. W. (2007). Qualitative inquiry and research design: Choosing among five approaches (2nd Ed). Thousand Oaks, CA: Sage.

Davies, J. (2004). Corruption in Public Service Delivery Experience from South Asia's Water and Sanitation Sector. World Development, 32(1), 53-71.

Davies, K.S. (2011). Formulating the Evidence Based Practice Question: A Review of the Frameworks.Evidence Based Library and Information Practice, 6(2), 75-80.

De Graaf, G. (2007). Causes of corruption: Towards a contextual theory of corruption [Online]. Available at: http://unpan1.un.org/intradoc/groups/public/documents/un-dpadm/unpan049603.pdf

Department for International Development. (2015). Why corruption matters: understanding causes, effects and how to address them. London: Department for International Development.

Gan Integrity. (2017). Zimbabwe Corruption Report [Online]. Available at: http://www.business-anticorruption.com/country-profiles/zimbabwe

Goel, R.K. \& Nelson, M.A. (2008). Causes of corruption: History, geography and government. Journal of Policy Modeling, 32(4), 433-447.

Gray, C.W. \& Kaufmann, D. (1998) Corruption and Development. Finance \& Development, 7-10.

Hove, M. \& Tirimboi, A. (2011). Assessment of Harare Water Service Delivery. Journal of Sustainable Development in Africa, 13(4), 61-84.

Ijewereme, O. B. (2015). Anatomy of Corruption in the Nigerian Public Sector: Theoretical Perspectives and Some Empirical Explanations. SAGE Open, 5(2), 1-16.

Jambawo, T. (2014). Leverage and Corporate Market Value: Empirical Evidence from Zimbabwe Stock Exchange. International Journal of Economics and Finance, 6(4), 185-195.

Kelly, K., Clark, B., Brown, V. \& Sitzia, J. (2003). Good practice in the conduct and reporting of survey research. International Journal for Quality in Health Care, 15(3), 261-266.

Labuschagne, H. \& Els, G. (2006). Corruption and fraud: any lessons for the auditor? Meditari Accountancy Research, 14(1), 29-47.

Leedy, P. \& Ormrod, J. (2013). Practical Research Planning and design. Boston: Pearson.

Likert, R. (1932). A technique for the measurement of attitudes. Archives of Psychology, 22(140), 1-55.

Makanyeza, C., Hardson P., Kwandayi, H.P. \& Ikobe, B.N. (2013). Strategies to Improve Service Delivery in Local Authorities. International Journal of Information Technology and Business Management, 15(1), $1-11$.

Makumbe, J. (2011). Political corruption as a driver of corruption' in Corruption Essays on the state of corruption in Zimbabwe under Government of national Unity. Open society initiative for Southern Africa.

Marquette, H. \& Peiffer, C. (2015) Corruption and Collective Action. Research Paper 32. The U4 AntiCorruption Resource Centre.

Mills, A. (2012). Causes of Corruption in public sector institutions and its impact on development: Turning what we know into what we do [Online]. Available at: http://unpan1.un.org/intradoc/groups/public/documents/un-dpadm/unpan049589.pdf

Moyo, G. (2012). The state of Corporate Governance in Zimbabwe's State Enterprises: Can the situation be rescued? [Online]. Available at: http://gordenmoyo.blogspot.com/2012/09/the-state-of-corporategovernance-in.html

Mtisis, S. (2008). Promoting Water Quality Laws Enforcement and Implementation in Zimbabwe's Urban Areas. Harare: Environmental Law Association.

Muvundusi, J. (2015). ZINWA owed \$115m. Daily News, 19 October, p.7.

Ncube, F. \& Maunganidze, L. (2014). Corporate Governance and Executive Compensation in Zimbabwean State Owned Enterprises: A Case of Institutionalized Predation. Management, 4(6), 131-140.

Nherera, D. (2016). Most suburbs to go without water. Suburban, 19-25 February, p.2.

Nsereko, D. D. N. \& Kebonang, Z. (2005). The SADC protocol against corruption: Example of the region's response to an international scourge. University of Botswana Law Journal, 1, 85-119.

Park, H. \& Blenkinsopp, J. (2011). The roles of transparency and trust in the relationship between corruption and citizen satisfaction. International Review of Administrative Sciences, 77(2), 254-274.

Persson, A., Rothstein, B. \& Teorell, J. (2013). Why Anticorruption Reforms Fail - Systemic Corruption as a Collective Action Problem. Governance, 26(3), 449-471. 
Porkess, K. (2011).Corruption at work - the exception that proves the rule? [Online]. Available at: https://blogs.exeter.ac.uk/exeterblog/blog/2011/09/30/corruption-at-work-\%E2\%80\%93-theexception-that-proves-the-rule/

Resnik, D.B. (2015). What is Ethics in Research \& Why is it Important? [Online]. Available at: http://www.niehs.nih.gov/research/resources/bioethics/whatis/

Saki, 0. \& Chiware, T. (2007). The Law in Zimbabwe [Online]. Available at: http://www.nyulawglobal.org/globalex/Zimbabwe.html

Selamawit, W. (2015). Corruption and service delivery (water supply and sanitation sector) in Fitche Town, Addis Ababa, Thesis. Addis Ababa University.

Seligson, M. A. (2006). The Measurement and Impact of Corruption Victimization: Survey Evidence from Latin America. World Development, 34(2), 381-404.

Sithole, A. (2013). Corruption in Zimbabwe Urban Local Authorities: A Case of Gweru City Council. Asian Journal of Social Sciences \& Humanities, 2(3), 26-33.

Steve, S. (2001). An overview of content analysis. Practical Assessment, Research \& Evaluation, 7(17), 137-146.

Svensson, J. (2005). Eight Questions about Corruption. Journal of Economic Perspectives, 19(3), 19-42.

Synodinos, N.E. (2003). The "art" of questionnaire construction: some important considerations for manufacturing studies. Integrated Manufacturing Systems, 14(3), 221-237.

Tizor, R.E. (2009). Bureaucratic corruption in Zimbabwe, Thesis. University of Oslo.

Transformation Index. (2016). Zimbabwe Country Report [Online]. Available at: http://www.btiproject.org/fileadmin/files/BTI/Downloads/Reports/2014/pdf/BTI_2014_Zimbabwe.pdf

Transparency International. (2016). Corruption Perceptions Index [Online]. Available at: https://www.transparency.org/research/cpi/

Treisman, D. (2000). The causes of corruption: a cross-national study. Journal of Public Economics, 76, 399457.

Van der Merwe, A. (2006). The Nature and Causes of Corruption: Perceptions of KZN Public service managers and anti-corruption. Journal of Public Administration, 41(1), 32-46.

World Bank. (1997). Corruption and Economic Development [Online]. Available at: http://www1.worldbank.org/publicsector/anticorrupt/corruptn/cor02.htm

Zhou, G. (2012). Three Decades of Public Enterprise Restructuring in Zimbabwe a will-Of-The-Wisp. International Journal of Humanities and Social Science, 2(20), 175-184.

Zivengwa, T., Mashika, J., Bokosi, F.K., \& Makova, T. (2011). Stock market development and economic growth in Zimbabwe. International Journal of Economics and Finance, 3(5), 140-150. 